\title{
Photocatalytically Active Zinc Oxide and Titanium Dioxide Nanoparticles in Clonal Micropropagation of Plants: Prospects
}

\author{
O. V. Zakharova ${ }^{a, b}$ and A. A. Gusev ${ }^{a, b, c, *}$ \\ ${ }^{a}$ Derzhavin Tambov State University, Tambov, Russia \\ ${ }^{b}$ National University of Science and Technology MISIS, Moscow, Russia \\ ${ }^{c}$ Morozov Voronezh State University of Forestry and Technologies, Voronezh, Russia \\ *e-mail: nanosecurity@mail.ru \\ Received October 25, 2019; revised November 18, 2019; accepted November 18, 2019
}

\begin{abstract}
The search for effective and nontoxic sterilization drugs for plants against common phytopathogenic microorganisms is a major challenge to improve the biotechnology of plant clonal micropropagation. An analysis of 92 studies that describe the potential use of $\mathrm{ZnO}$ and $\mathrm{TiO}_{2}$ nanoparticles as antimicrobial agents in biotechnology showed that their biological effects depend on several factors: photocatalytic activity, particle size, concentration, morphology, and surface modification. The mechanisms of toxicity, among which the primary one is generation of reactive oxygen species leading to oxidative stress, are also due to these factors. The data describing the direct influence of $\mathrm{ZnO}$ and $\mathrm{TiO}_{2}$ nanoparticles on plants, however, are contradictory, which is probably because of the various particle shapes and sizes, their concentrations, and the species characteristics of the plants studied. These studies have confirmed that photocatalytically active $\mathrm{ZnO}$ and $\mathrm{TiO}_{2}$ nanoparticles may be used as bactericidal and fungicidal drugs for sterilization of explants during clonal micropropagation of plants, while taking into account the possible phytotoxicity of these particles.
\end{abstract}

DOI: $10.1134 / \mathrm{S} 1995078019040141$

\section{INTRODUCTION}

One of the main problems that arise during preparation of planting material is phytopathologies caused by various microorganisms: fungi and, less often, bacteria together with viruses. Microbial contamination is a serious threat, especially for plant tissue culture, because it can destroy explants. The organs obtained from plants under field conditions or in a greenhouse have previously undergone surface sterilization prior to introduce into the culture. The disinfection of explants is an important step before in vitro cultivation, because microorganisms in the growth medium grow faster than explants and can seriously affect the results of microclonation. Sterilization, however, often seems to be rather ineffective. Disinfectants (bromine water, calcium hypochlorite, ethanol, hydrogen peroxide, sodium hypochlorite, mercuric chloride, silver nitrate, antibiotics, and fungicides) are conventionally used to obtain sterile explants, but an increase in the concentration of disinfectants and the time required for sterilization negatively affect the quality and viability of explants. In addition, some substances are phytotoxic [1,2].

Nanoparticles and nanomaterials are currently considered to be "new antibiotics." In particular, zinc oxide and titanium dioxide nanoparticles [3, 4] (Figs. 1, 2) are promising antimicrobial agents, because they possess photocatalytic activity, high penetration, and relative safety for multicellular organisms, at least in comparison with many other means for sterilization of explants.

It should be noted that nanoparticles may also be used in the preparation of various sensors, herbicides, phytoimmunity stimulants, and agents for pesticide removal from plants and soil, in addition to the development of nanopesticides (Fig. 3) [5].

\section{Antibacterial Properties of $\mathrm{ZnO}$ and $\mathrm{TiO}_{2}$ Nanoparticles}

Nanosized zinc oxide can possess high antibacterial activity against various bacteria and fungi, and a significant number of works confirms this fact [6-13]. The bactericidal properties of zinc oxide are currently being studied in both the macro- and nanoforms. The authors have shown that $\mathrm{ZnO}$ has greater antimicrobial activity when the particle size decreases to the nanometer range, because $\mathrm{ZnO}$ nanoparticles can interact with the cell surface and/or nucleus during penetration into the cell [9].

Although the biocidal activity of $\mathrm{ZnO}$ has been studied quite well, the exact mechanism of toxicity is not fully explained and is controversial. The main possible mechanism discussed in the literature is the following: direct contact of zinc oxide nanoparticles with the cell walls, leading to the destruction of membranes 

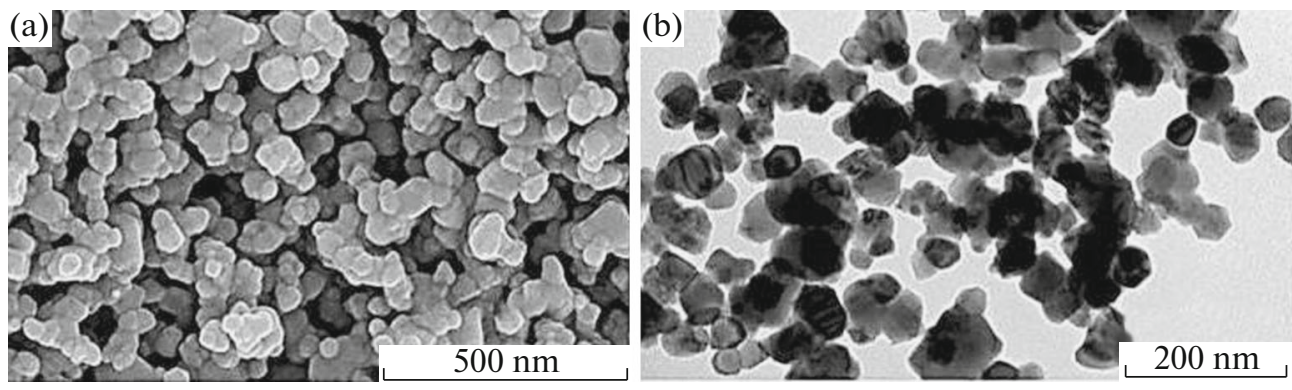

Fig. 1. Microphotographs of $\mathrm{ZnO}$ nanoparticles: (a) SEM and (b) TEM [3].
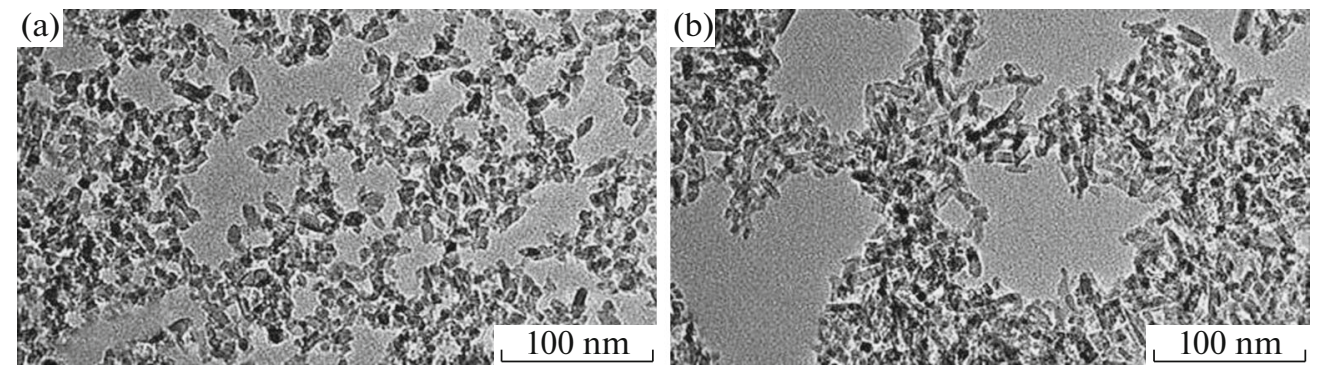

Fig. 2. TEM images of $\mathrm{TiO}_{2}$ nanoparticles: (a) anatase and (b) rutile [4].

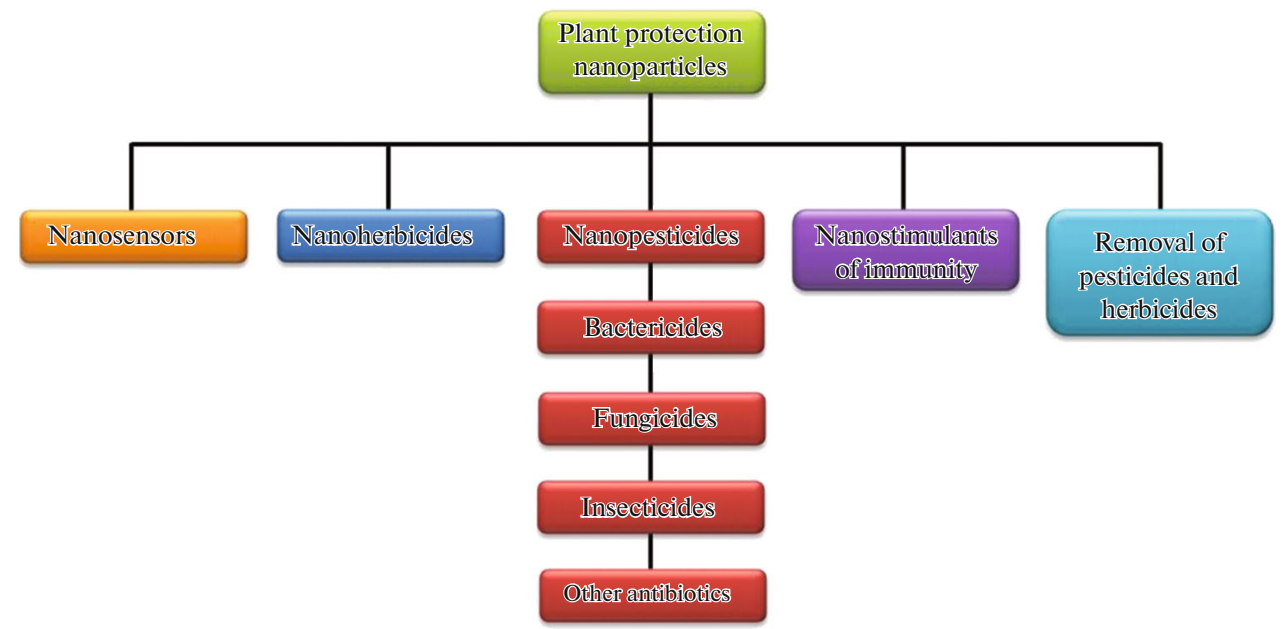

Fig. 3. (Color online) Directions for the use of nanoparticles in plant protection.

$[6,13-15]$, the release of antimicrobial ions (mainly $\mathrm{Zn}^{2+}$ ), and the formation of reactive oxygen species $[16,17]$.

$\mathrm{ZnO}$ possesses the highest photocatalytic activity among all inorganic photocatalytic materials [18]. $\mathrm{ZnO}$ can effectively absorb UV radiation [19], and, therefore, its photoactivity increases; this feature significantly enhances the interaction between $\mathrm{ZnO}$ and bacteria. The activity of $\mathrm{ZnO}$ remains unchanged even after UV radiation is turned off, which is due to the electron depletion region owing to negative oxygen atoms $\left(\mathrm{O}^{-2}\right.$ and $\left.\mathrm{O}_{2}^{-2}\right)$ adsorbed on the surface [20]. Zinc oxide nanoparticles in an aqueous solution under UV radiation have a phototoxic effect based on the production of $\mathrm{H}^{2} \mathrm{O}^{2}$ and $\mathrm{O}^{2-}$ reactive oxygen species. A detailed reaction mechanism explaining this phenomenon was proposed earlier (Fig. 4) [11, 21, 22].

A higher antibacterial effect of zinc oxide nanoparticles was detected after UV irradiation against Escherichia coli and Staphylococcus aureus (98.65 and $99.45 \%$, respectively) [23]. $\mathrm{ZnO}$, however, possesses significant activity against bacteria under various test 


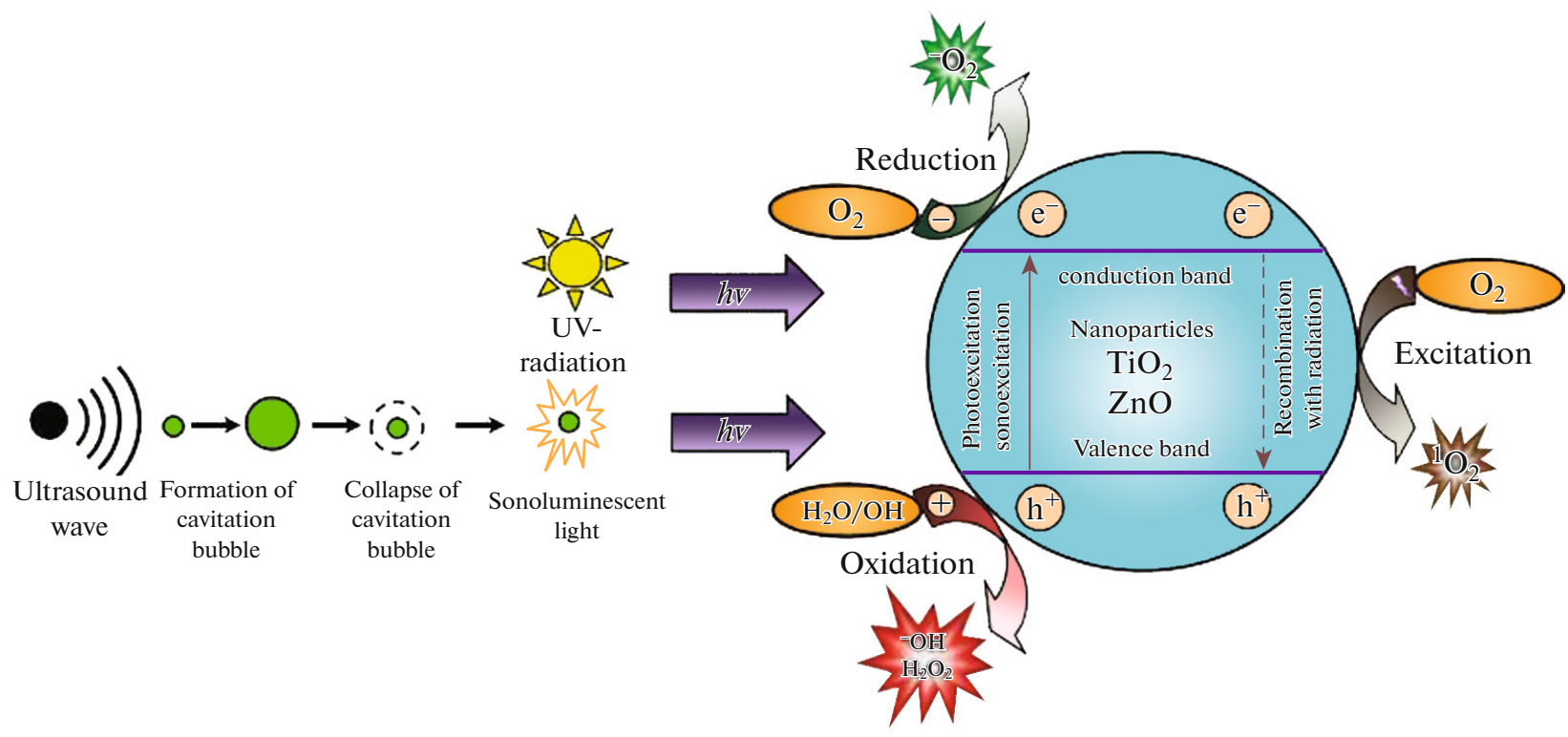

Fig. 4. (Color online) Mechanisms for the generation of reactive oxygen species [22].

conditions (conventional lighting and in the dark) $[7,24]$.

Many studies have shown that the various morphological parameters of $\mathrm{ZnO}$ nanoparticles, which are due to the synthesis conditions, influence the toxicity significantly $[25,27]$. Desirable characteristics can be achieved by variation of the following parameters: the solvent, precursor, temperature, $\mathrm{pH}$ [28], and agents that regulate the form.

The antibacterial effect of $\mathrm{ZnO}$ nanoparticles in three different forms (nanorods, nanoflakes, and nanospheres) impregnated into low density polyethylene (LDPE) against $S$. aureus ATCC 25923 was studied [29]. An analysis performed according to ASTM E-2149 showed that $\mathrm{ZnO}$ nanospheres had the greatest inhibition of $S$. aureus. The shape of $\mathrm{ZnO}$ nanostructures can affect their internalization mechanism, because nanorods and nanowires can more easily penetrate bacterial cell walls than spherical nanoparticles [30]. At the same time, flower-shaped nanoparticles have a higher efficiency against $S$. aureus and $E$. coli than spherical and rod-shaped ones [31]. It was suggested that the polar faces of $\mathrm{ZnO}$ contribute to biochemical activity in addition to enhancement of internalization of zinc oxide nanoparticles through variation of the shape. In other words, more polar surfaces have a higher amount of oxygen vacancies. It is known that oxygen vacancies increase the generation of reactive oxygen species and, therefore, affect the photocatalytic activity of $\mathrm{ZnO}$ [31].

The antibacterial activity of nanoparticles correlates directly with their concentration and depends on the size of particles. A large surface area and a higher concentration enhance the antibacterial effect of $\mathrm{ZnO}$ nanoparticles [14, 32]. Smaller particles can easily penetrate bacterial membranes. The influence of the size $(100-800 \mathrm{~nm})$ of $\mathrm{ZnO}$ particles on their properties against $S$. aureus and $E$. coli was studied [33]. The authors found that antibacterial activity increases with a decrease in particle size. Similar effects were observed in other studies [7, 11, 14].

The size-dependent bactericidal activity was assessed [12]. The authors analyzed the reaction of a number of gram-negative and gram-positive strains. They found that the antibacterial activity of $\mathrm{ZnO}$ nanoparticles is inversely proportional to the particle size. An analysis of the growth and viability curves of bacteria showed that the activity of nanoparticles depends on the size; i.e., smaller particles have a greater antimicrobial effect under visible light. These data indicate that $\mathrm{ZnO}$ nanoparticles with a very small size $(\sim 12 \mathrm{~nm})$ inhibited about $95 \%$ growth compared to that of the control. In addition, the influence of particles of various sizes $(307,212,142,88$, and $30 \mathrm{~nm})$ on bacterial growth at a concentration of $6 \mathrm{mmol}$ was studied. The amount of viable cells decreased significantly with a decrease in particle size, which is due to the higher reactivity of small nanoparticles [11].

The authors also found that the antibacterial activity depends on the concentration and crystal structure of $\mathrm{ZnO}$ [34]. When the concentration was increased, bacterial survival decreased. A possible mechanism of toxicity, as the authors assumed, is violation of mitochondrial function, leakage of lactate dehydrogenase, and a change in the cell morphology under the action of nanoparticles.

The influence of the dispersion medium and the storage time of suspensions of zinc oxide nanoparticles 


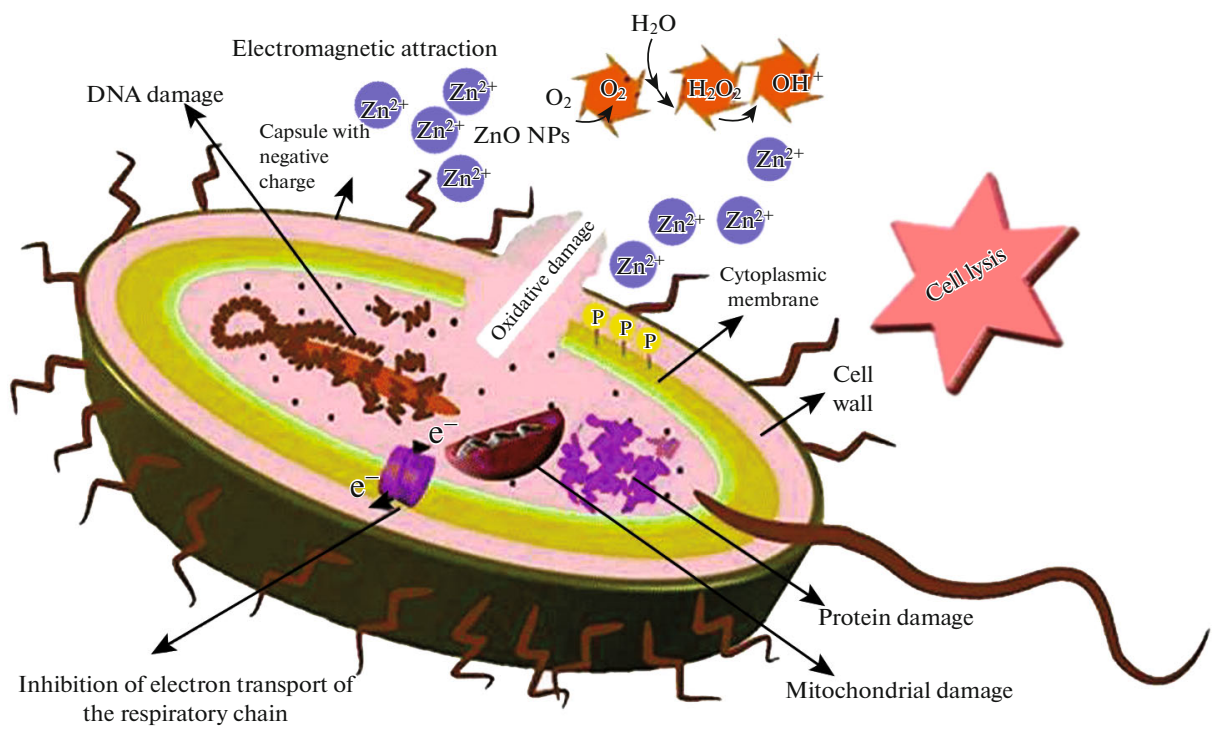

Fig. 5. (Color online) The mechanism of antibacterial action of $\mathrm{ZnO}$ nanoparticles on $S$. typhi as an example [36].

on their antibacterial activity against the $E$. coli luminescent strain was studied [35]. The authors found that freshly prepared aqueous dispersions of nanoparticles at concentrations of $1,10,100$, and $1000 \mathrm{mg} / \mathrm{L}$ had the maximum activity: the survival rate was less than 5\%; when the concentration decreased to $0.001 \mathrm{mg} / 1$, the survival rate increased to $25 \%$. After one day, the survival rate remained unchanged only at high concentrations (1, 10, 100, and $1000 \mathrm{mg} / \mathrm{L})$, whereas it was $80-90 \%$ at lower concentrations. When the aqueous environment was replaced with physiological saline $(0.9 \% \mathrm{NaCl})$, the survival rate was less than $5 \%$ only at 10,100 , and $1000 \mathrm{mg} / \mathrm{L}$, regardless of the storage time; when the concentration of nanoparticles was decreased, the biocidal effect disappeared at $0.001 \mathrm{mg} / \mathrm{L}$.

There is an electromagnetic attraction between negatively charged bacteria and positively charged $\mathrm{ZnO}$ nanoparticles to form bonds between them. $\mathrm{ZnO}$ nanoparticles interact with membrane lipids and thiol groups $(-\mathrm{SH})$ of enzymes and proteins, which are important for bacterial respiration, transmembrane transport, and intracellular transport. In addition, $\mathrm{ZnO}$ nanoparticles can penetrate into bacterial cells and inactivate phosphorus and sulfur compounds, such as DNA and enzymes. The generation of reactive oxygen species (ROSs) plays a key role in this process, because damage to membranes, DNA, and cellular proteins is due to ROSs [36]. This process is shown schematically in Fig. 5.

Nanosized $\mathrm{TiO}_{2}$ is also effective in suppressing bacteria [21, 37-41].

Its antibacterial activity depends on the light intensity [42], particle concentration and diameter [43, 44], ambient temperature [45], substrate chemical compo- sition [46, 47], and species sensitivity of microorganisms $[48,49]$.

The influence of two $\mathrm{TiO}_{2}$ anatase types (25 and $100 \mathrm{~nm}$ ) on the bacterial community in a filter with biologically activated carbon was assessed with DNA analysis [50]. Both nanoparticle types significantly inhibited the level of bacterial adenosine triphosphate (ATP) $(p<0.01)$ and decreased the amount of copies of the $16 \mathrm{~S}$ rDNA bacterial gene at 0.1 and $100 \mathrm{mg} / \mathrm{L}$. At the same time, the diversity and uniformity of bacterial communities were significantly decreased. The relative amount of Nitrospira and Betaproteobacteria bacteria decreased after treatment with $\mathrm{TiO}_{2}$, whereas the amount of Bacilli and Gammaproteobacteria bacteria increased. The size of $\mathrm{TiO}_{2}$ particles had a greater effect on the bacterial composition than their concentration.

Hollow calcined nanospheres of titanium dioxide $\left(\mathrm{CSTiO}_{2}\right)$, with a size of about $345 \mathrm{~nm}$ and a shell thickness of $17 \mathrm{~nm}$ and obtained by electrospinning and subsequent deposition onto the atomic layer, were studied [51]. The antibacterial activity of $\mathrm{CSTiO}_{2}$ was assessed by the inhibition of growth of $S$. aureus (ATCC®6538TM control strain together with MRSA 97-7 and MRSA 622-4 resistant strains) and E. coli (ATCC®25922TM control strain and E. coli 33.1 resistant strain). Commercial titanium dioxide nanoparticles were used in the experiment for comparison. The studies showed that $\mathrm{CSTiO}_{2}$ had greater antibacterial activity against $S$. aureus and $E$. coli compared to that of commercial nanoparticles. At the same time, only $\mathrm{CSTiO}_{2}$ had low antibacterial activity against $E$. coli MRSA 33.1 in the study with resistant bacteria. The authors assume that such a low efficiency is probably due to the high resistance of bacteria to a wide range of 
exposure agents. UV radiation was used to enhance the antibacterial effect. After exposure for $60 \mathrm{~min}$, the inhibitory effect of $\mathrm{CSTiO}_{2}$ at a concentration of $100 \mu \mathrm{g} / \mathrm{mL}$ against $S$. aureus MRSA 97-7 increased significantly; no similar effect was observed for $\mathrm{TiO}_{2}$ nanoparticles.

\section{Fungicidal Action of $\mathrm{ZnO}$ and $\mathrm{TiO}_{2}$ Nanoparticles}

Numerous studies indicate that zinc oxide nanoparticles possess a fungicidal effect. Indeed, $\mathrm{ZnO}$ nanoparticles obtained by the sol-gel method with a 0.15 and $0.1 \mathrm{M}$ precursor (zinc acetate dihydrate) inhibited the mycelial growth of the fungus Erythricium salmonicolor [52]. The inhibitory effect on fungal growth was studied by measuring the growth area as a function of time. Morphological changes were observed with high resolution optical microscopy (HROM), whereas transmission electron microscopy (TEM) was used to monitor changes in the ultrastructure. The results showed that the sample with a concentration of $9 \mathrm{mmol} / \mathrm{L}$ obtained from $0.15 \mathrm{M}$ and $12 \mathrm{mmol} / \mathrm{L}$ for the $0.1 \mathrm{M}$ system significantly inhibited the growth of E. salmonicolor. HROM images showed that there was a deformation in the growth structure: a noticeable thinning of hyphal fibers and a tendency to thicken. TEM results showed a liquefaction of the cytoplasmic contents, a decrease in its electron density in the presence of vacuoles, and significant damage to the cell wall.

The authors assessed the effects of $\mathrm{ZnO}$ nanoparticles on the viability of the pathogenic yeast Candida albicans [53]. They found that the effect of $\mathrm{ZnO}$ on the viability of $C$. albicans depends on the concentration. They also found that the minimum fungicidal concentration of $\mathrm{ZnO}$ is $0.1 \mathrm{mg} / \mathrm{mL}$; it inhibited more than $95 \%$ of C. albicans growth. $\mathrm{ZnO}$ nanoparticles also inhibited the growth of $C$. albicans when added to the logarithmic phase of growth. The addition of histidine (an inactivator of hydroxyl radicals and singlet oxygen) decreased the effect of $\mathrm{ZnO}$ on $C$. albicans depending on the concentration. The antimycotic effect was almost completely eliminated after adding $5 \mathrm{mmol}$ of histidine. The excitation of $\mathrm{ZnO}$ with visible light increased the death of yeast cells. These effects of histidine imply that ROSs play a significant role, including hydroxyl radicals and singlet oxygen, in cell death.

The antifungal activity of zinc oxide nanoparticles with a size of $70 \pm 15 \mathrm{~nm}$ at concentrations of $0,3,6$, and $12 \mathrm{mmol} / \mathrm{L}$ and the mechanism of their action against two pathogenic fungi (Botrytis cinerea and Penicillium expansum) were studied [54]. The results showed that $\mathrm{ZnO}$ nanoparticles at concentrations of more than $3 \mathrm{mmol} / \mathrm{L}$ can significantly inhibit the growth of $B$. cinerea and $P$. expansum. P. expansum was more sensitive to $\mathrm{ZnO}$ treatment than $B$. cinerea. Scanning electron microscopy (SEM) and Raman spectroscopy data showed that there are two different antifungal mechanisms of $\mathrm{ZnO}$ against $B$. cinerea and $P$. expansum (Figs. 6, 7). $\mathrm{ZnO}$ nanoparticles inhibited the growth of $B$. cinerea, affecting cellular functions, which led to the deformation of fungal hyphae. In the case of $P$. expansum, $\mathrm{ZnO}$ nanoparticles prevented the growth of conidiophores and conidia, which ultimately led to the death of hyphae [54].

The antifungal activity of $\mathrm{ZnO}$ nanoparticles obtained under various synthesis conditions was assessed against Colletotrichum gloeosporioides strains [55]. In vitro activity was found by calculation of the minimum inhibitory concentrations (MICs). A clear fungicidal effect was observed against two C. gloeosporioides strains that had led to anthracnose in avocados and papayas. The MICs to suppress the pathogen isolated from papaya were 0.156 and $0.312 \mathrm{mg} / \mathrm{mL}$ for the avocado fungus, regardless of the method to prepare the nanomaterial. The inhibition of radial growth of the mycelium in the presence of nanoparticles was 60 , 70 , and $80 \%$ at concentrations of $0.156,0.312$, and $0.624 \mathrm{mg} / \mathrm{mL}$, respectively.

$\mathrm{ZnO}$ nanoparticles inhibit the growth of Penicillium expansum at $0.5 \mathrm{mmol}$; the fungicidal effect intensified with an increase in concentration, and the pathogen was almost completely suppressed at $15 \mathrm{mmol}$ [56].

The first studies to assess the effectiveness of $\mathrm{TiO}_{2}$ against fungi appeared in 1985 [57]. They proved that the amount of Saccharomyces cerevisiae cells inactivated in vitro after $240 \mathrm{~min}$ of UV-A irradiation increased from 72 to $98 \%$ in the presence of a $0.5 \%$ colloidal solution of $\mathrm{TiO}_{2}$ nanoparticles. In addition, $\mathrm{TiO}_{2}$ nanoparticles did not penetrate $S$. cerevisiae cells even after prolonged exposure, despite an increase in the ROS concentration in the cytosol [58]. These results indicate that the cell wall and plasma membrane were damaged insignificantly. The fungicidal properties of nanosized $\mathrm{TiO}_{2}$ were also observed against other $C$. albicans fungi [21, 40, 59-62]. Moreover, recent studies showed that $\mathrm{TiO}_{2}$ nanoparticles can be used to inactivate the mold species Fusarium sp. [41, 63], Aspergillus niger [21, 60, 64], and Penicillium expansum [65]. The relative resistance of fungi to photocatalytic oxidation is probably due to the protective effect of polysaccharides in the cell wall [66].

The effect of titanium dioxide nanoparticles on Hypocrea lixii (white rot) and Mucor circinelloides (brown rot), which are responsible for the rapid decay of wood, was studied [67]. The results showed that the photocatalytic activity of titanium dioxide nanoparticles prevents the fungal colonization of wood treated with suspensions of nanoparticles for a long time compared to untreated wood (Fig. 8).

\section{Influence of $\mathrm{ZnO}$ and $\mathrm{TiO}_{2}$ Nanoparticles on Plants}

When nanoparticles are used as agents to sterilize explants, an important point is the analysis of their 

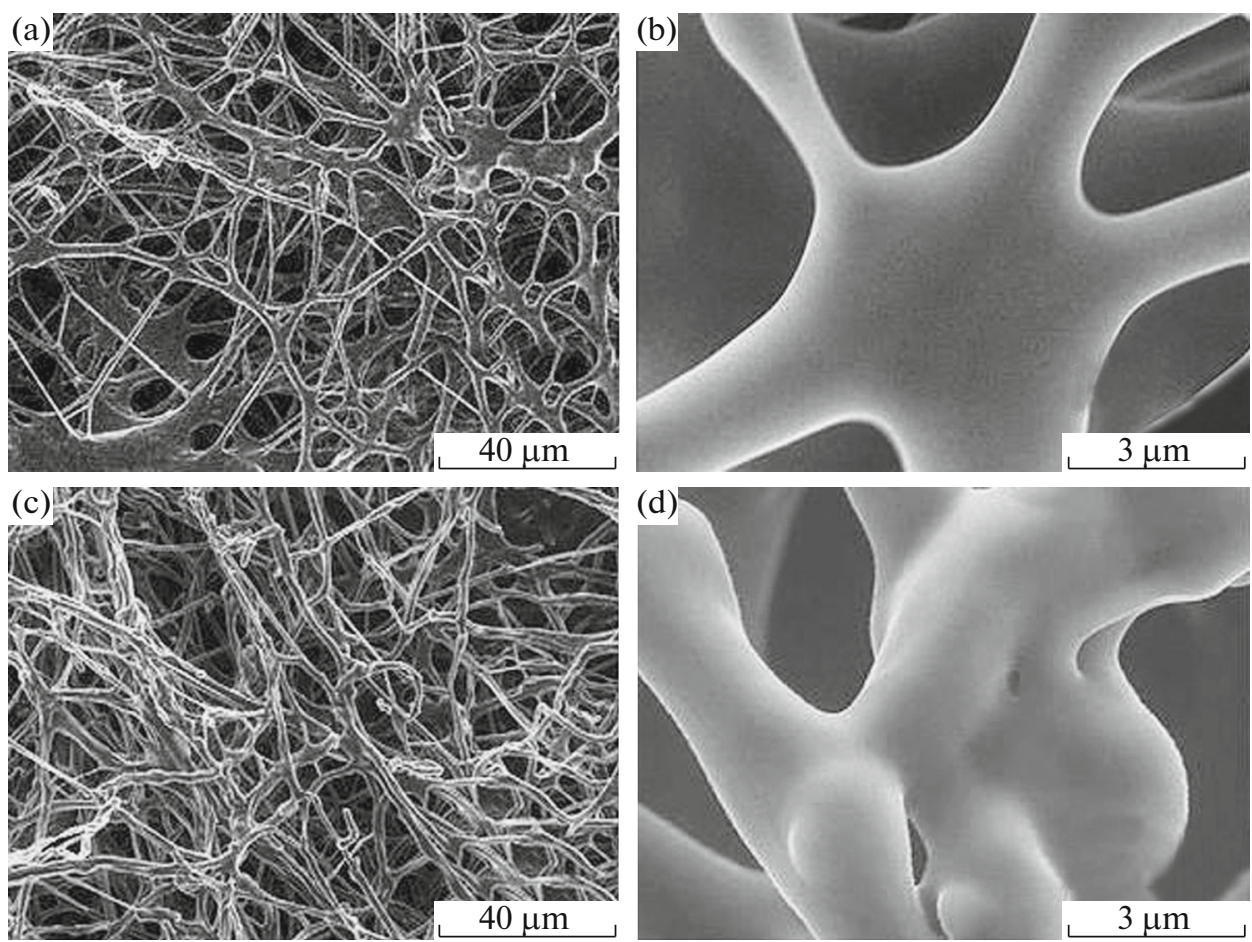

Fig. 6. SEM images of Botrytis cinerea: (a, b) control and (c, d) after treatment with ZnO [54].
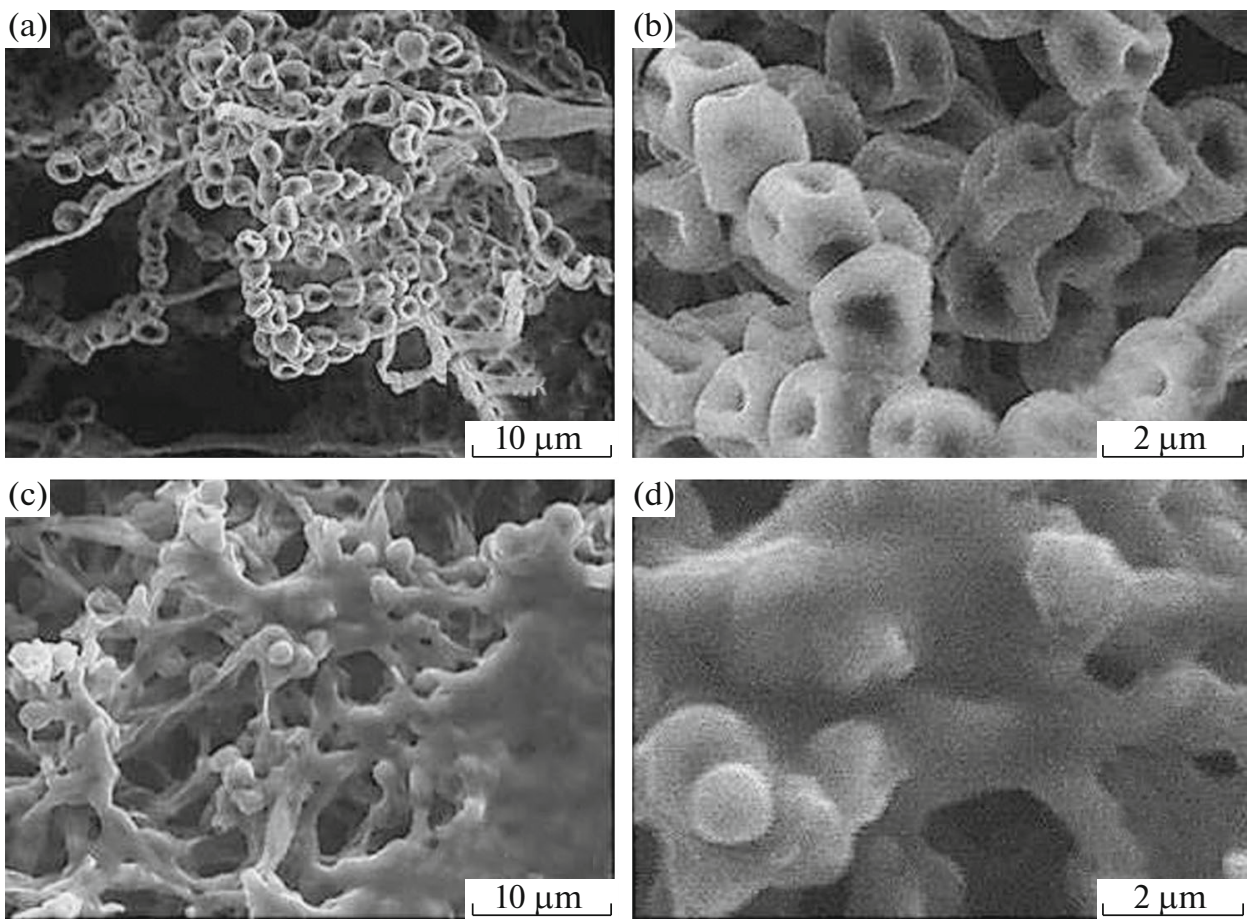

Fig. 7. SEM images of Penicillium expansum: $(\mathrm{a}, \mathrm{b})$ control and $(\mathrm{c}, \mathrm{d})$ after treatment with $\mathrm{ZnO}$ [54].

effect on plants. Zinc is an important essential element involved in many physiological processes in plants [68]. It is an integral component of special proteins (zinc fingers), which bind to DNA and RNA and con- tribute to their regulation and stabilization [69]. Zinc is an integral part of various enzymes, for example, oxidoreductases, transferase, and hydrolases [70], as well as ribosomes [71]. It plays an important role in the 
formation of carbohydrates and chlorophyll and for the growth of plant roots [72].

At the same time, zinc oxide nanoparticles can negatively effect plant organisms. Indeed, the germination of corn seeds decreased under the influence of $2000 \mathrm{mg} / \mathrm{L}$ of $\mathrm{ZnO}$ nanoparticles [73]. The length of the roots and stems of wheat decreased by 35 and $30 \%$ under the action of zinc oxide nanoparticles at a concentration of $1000 \mathrm{mg} / \mathrm{L}$, whereas the same parameters for cucumber plants decreased by 65 and $25 \%$, respectively [74]. The biomass of buckwheat plants (Fagopyrum esculentum) decreased, and root cells were damaged under the action of $10-2000 \mathrm{mg} / \mathrm{L}$ of zinc oxide in the substrate [75].

Treatment with $\mathrm{ZnO}$ dispersion nanoparticles significantly inhibited the growth of tomato roots and shoots: the biomass decreased by about $10 \%$ after treatment of $400 \mathrm{mg} / \mathrm{dm}^{3}$ of a substrate with $\mathrm{ZnO}$ and by $50 \%$ of plants treated with $800 \mathrm{mg} / \mathrm{dm}^{3}$. The amount of chlorophylls $a$ and $b$ and the efficiency of photosynthesis also decreased. The authors assumed that toxicity was probably because of damage to the photochemical system, which limited photosynthesis and decreased biomass accumulation. $\mathrm{ZnO}$ nanoparticles also enhanced the transcription of genes of the antioxidant system, which is probably due to the fact that $\mathrm{ZnO}$ can enhance the protective response by an increase in the activity of antioxidant enzymes [76].

$\mathrm{ZnO}$ nanoparticles can affect the germination capacity of eggplant seeds depending on the cultivation medium [77]. Indeed, when seeds were germinated in the Murashige-Skoog medium, germination was inhibited with an increase in the concentration of nanoparticles from 5 to $20 \mathrm{mg} / \mathrm{L}$ and it decreased by more than $50 \%$ relative to the control at the maximum concentration. At the same time, germination in a peat medium was $100 \%$ at a concentration of nanoparticles of 20 and $100 \mathrm{mg} / \mathrm{kg}$; when the concentration decreased to $5 \mathrm{mg} / \mathrm{kg}$, germination decreased by $20 \%$. Similar effects were observed for biomass growth. It especially should be noted that the maximum increase in length $(\sim+25 \%)$ and mass $(\sim+50 \%)$ of the root was observed when the concentration of peat was $100 \mathrm{mg} / \mathrm{kg}$.

After treatment with 1000 and 1200 ppm of zinc oxide, $100 \%$ germination of seeds of corn plants was observed, whereas only $60 \%$ of the seeds germinated in the control. An increase in the concentration of nanoparticles to $1600 \mathrm{ppm}$, however, led to a decrease in the parameter to $40 \%$. The authors also found that when the concentration of $\mathrm{ZnO}$ was $1200 \mathrm{ppm}$, there was a maximum increase in the plant biomass [78]. These results may be used to create conditions for better rooting of plants during clonal micropropagation and to transfer microclones from a test tube to soil conditions.

Onion plants treated with $\mathrm{ZnO}$ nanoparticles at a concentration of 20 and $30 \mu \mathrm{g} / \mathrm{mL}$ showed better growth and bloomed 12-14 days earlier than control

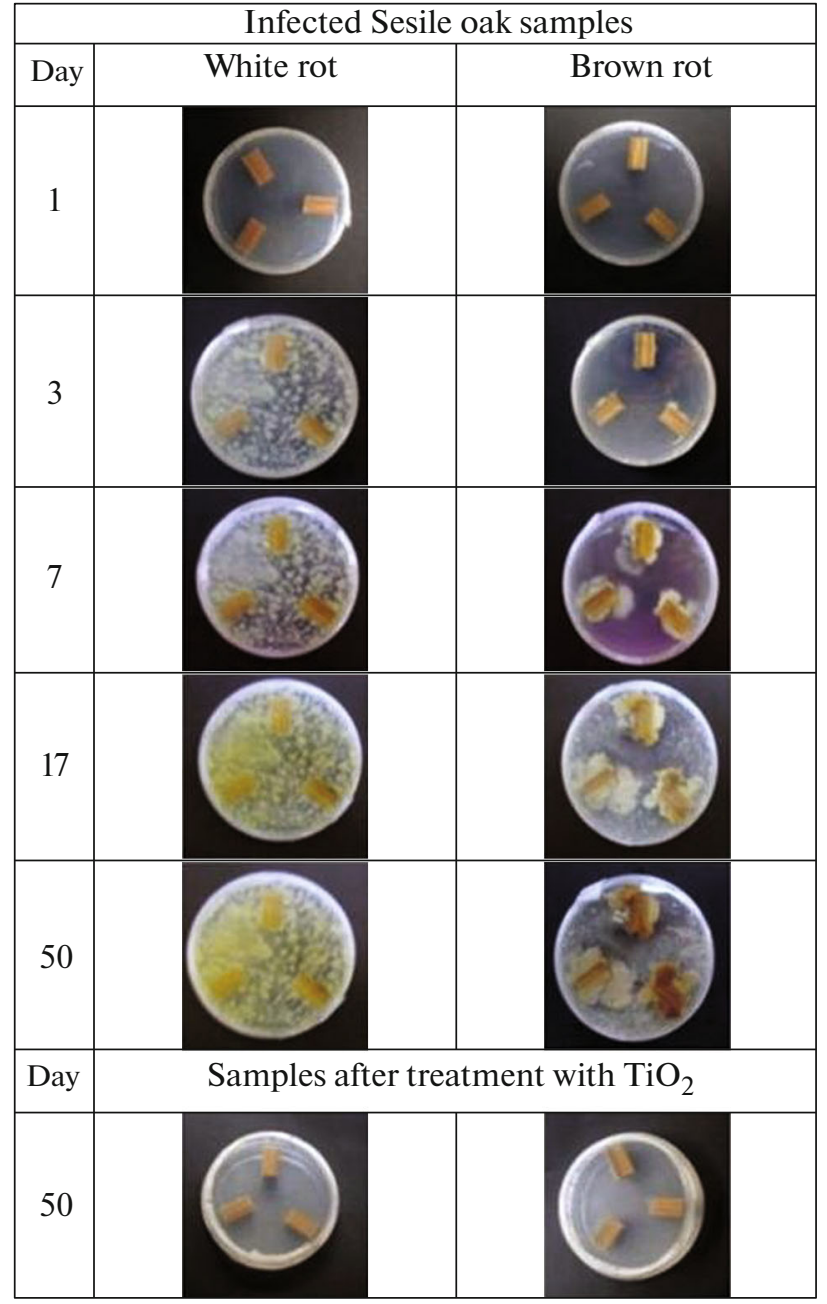

Fig. 8. (Color online) Mushroom growth on untreated and treated $\mathrm{TiO}_{2}$ samples of Sessile oak [67].

plants [79]. The plants treated had higher values for seeds per umbel, seed weights per umbel, and 1000 seeds. Similar results indicate that $\mathrm{ZnO}$ nanoparticles can accelerate plant vegetation and provide better planting material.

The influence of $\mathrm{ZnO}$ nanoparticles on the biochemical parameters of safflower plants was studied [80]. The results showed that the amount of malondialdehyde increased at all concentrations of zinc oxide $(10,100,500$, and $1000 \mathrm{mg} / \mathrm{L})$, which is probably due to the activation of free radical reactions in the cells. The amount of guaiacol peroxidase, polyphenol oxidase, and dehydrogenase increased at concentrations of $100,10,500$, and $1000 \mathrm{mg} / \mathrm{L}$, respectively; in addition, the amount of dehydrogenase decreased at other concentrations. These data indicate that antioxidant systems are activated in the presence of nanoparticles, which is probably due to stress for plants.

The growth characteristics, the activity of photosynthesis, and biomass of wheat plants increased pro- 

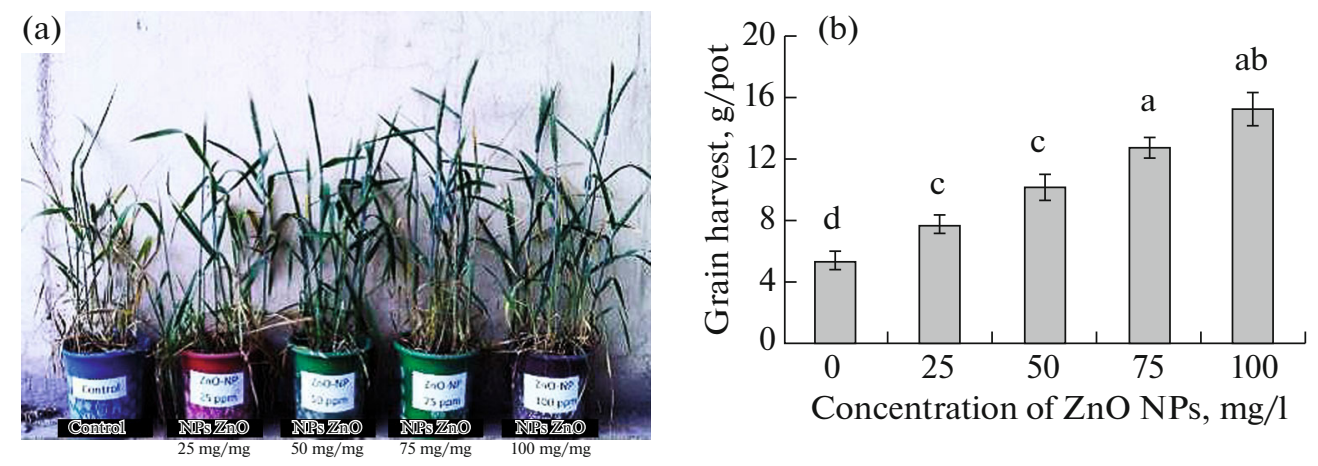

Fig. 9. (Color online) The influence of $\mathrm{ZnO}$ nanoparticles on wheat at concentrations of 25, 50, 75, and $100 \mathrm{mg} / \mathrm{L}$ [81].

portionally to the number of nanoparticles after treatment with $\mathrm{ZnO}$ nanoparticles at concentrations of 25 , 50, 75, and $100 \mathrm{mg} / \mathrm{L}$ (Fig. 9) [81]. An analysis of zinc accumulation showed that its concentration also increased linearly compared to the control: by 25,43 , 51 , and $65 \%$ in the shoots; by $20,21,29$, and $43 \%$ in roots; and by $8,35,50$, and $64 \%$ in grains [81].

Treatment with zinc oxide nanoparticles increased the rate of germination of capsicum seeds (Capsicum annuиm L.) during the first seven days [82]. Germination increased by $12.50,129.40$, and $94.17 \%$ after treatment with $\mathrm{ZnO}$ suspensions of 100, 200, and $500 \mathrm{ppm}$, respectively. Analysis of the morphological parameters showed that treatment with nanoparticles did not have a significant effect on the development of the plume, but affected significantly $(p \leq 0.01)$ the root length. The suspensions of nanoparticles $(100,200$, and $500 \mathrm{ppm}$ ) inhibited the growth of roots and contributed to the accumulation of phenolic compounds in these organs.

The authors assessed the influence of various zinc compounds on the physiological reactions of habanero pepper plants (Capsicum chinense Jacq.) under greenhouse conditions [83]. They found that $\mathrm{ZnO}$ nanoparticles at a concentration of $1000 \mathrm{mg} / \mathrm{L}$ had a positive effect on plant height, stem diameter, and the amount of chlorophyll; it also increased the yield and biomass accumulation compared to that sample treated with $\mathrm{ZnSO}_{4}$. Zinc oxide at a concentration of $2000 \mathrm{mg} / \mathrm{L}$ negatively affected the growth of plants, but significantly improved the quality of the fruit: the amount of capsaicin and dihydrocapsaicin increased by 19.3 and $10.9 \%$, respectively; the Scoville Heat Units (SHUs) increased by $16.4 \%$. In addition, $\mathrm{ZnO}$ nanoparticles at $2000 \mathrm{mg} / \mathrm{L}$ also increased the amount of total phenols and total flavonoids (soluble + bound) in fruits (14.50 and $26.9 \%$, respectively).

The influence of titanium dioxide in macroforms and nanoforms on seed germination, morphometric parameters of seedlings, and photosynthetic pigments of peppermint (Mentha piperita) was studied [84]. The authors showed that titanium dioxide samples at con- centrations of 100,200 , and $300 \mathrm{mg} / \mathrm{L}$ inhibited seed germination. The development of seedlings was also suppressed; an exception was the case when the concentration of $\mathrm{TiO}_{2}$ nanoparticles was $100 \mathrm{mg} / \mathrm{L}$, which led to an increase in the root length relative to the control. The amount of chlorophyll $a$ and $b$ increased under the action of $\mathrm{TiO}_{2}$ nanoparticles by more than two times, regardless of the concentration. Macroform titanium dioxide had a positive effect only at $200 \mathrm{mg} / \mathrm{L}$. The amount of carotenoids increased more than two times relative to the control after treatment with $100 \mathrm{mg} / \mathrm{L} \mathrm{TiO}_{2}$, whereas macroform titanium dioxide at $200 \mathrm{mg} / \mathrm{L}$ increased this parameter by more than three times.

The influence of $\mathrm{TiO}_{2}$ nanoparticles on the production and quality of rosemary essential oil (Rosmarinus officinalis) was assessed [85]. The experimental treatment included the sputtering of $\mathrm{TiO}_{2}$ nanoparticles in concentrations of $20,40,60,100,200$, and $400 \mathrm{ppm}$ on rosemary leaves. The results showed that the amount of many compounds in the essential oil with $\mathrm{TiO}_{2}$ nanoparticles increased. This indicator, however, decreased at high concentrations (more than $200 \mathrm{ppm}$ ). An analysis of the amount of $\alpha$-pinene, caryophyllene, and other compounds in the essential oil showed that it increased as much as possible, when the concentration of $\mathrm{TiO}_{2}$ nanoparticles was $200 \mathrm{ppm}$.

The treatment of tomato seeds with suspensions of titanium dioxide nanoparticles $(25 \mathrm{~nm})$ at a concentration of $1000 \mathrm{mg} / \mathrm{L}$ significantly decreased the germination energy [86]. At the same time, there was no effect after the treatment of tomato seeds with $\mathrm{TiO}_{2}$ dispersive nanoparticles $(27 \mathrm{~nm})$ at concentrations up to $4000 \mathrm{mg} / \mathrm{L}$ [87].

$\mathrm{TiO}_{2}$ nanoparticles also inhibited the rate of seed germination of maize and Narbonne peas [88]. The seed germination of soft wheat plants decreased in the presence of anatase titanium dioxide at a concentration of $150 \mathrm{mg} / \mathrm{L}$, whereas no such effect was observed, when anatase and rutile were mixed [89].

The authors found that $\mathrm{TiO}_{2}$ anatase nanoparticles of about $3 \mathrm{~nm}$ in size penetrated into Arabidopsis thali- 


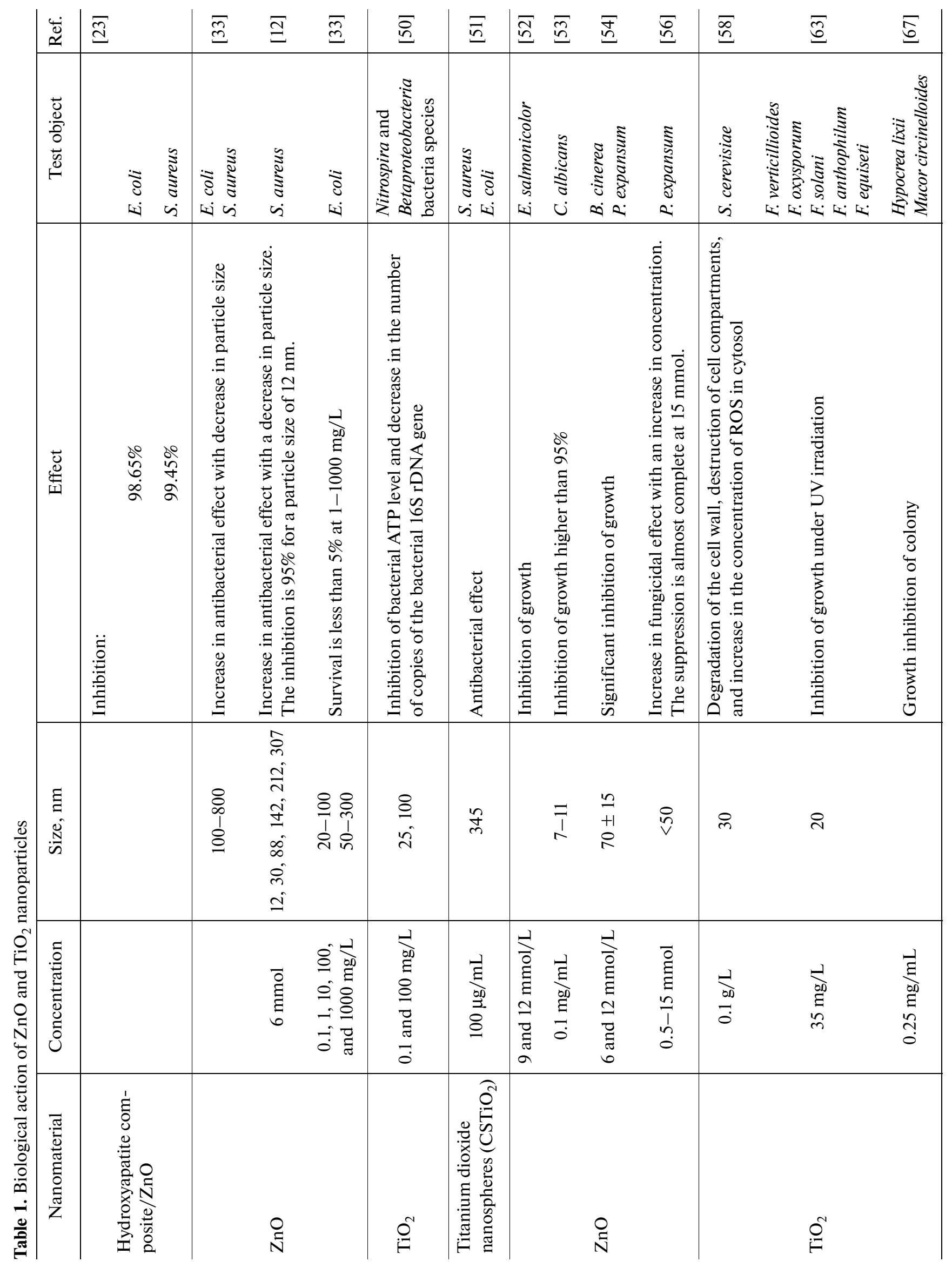




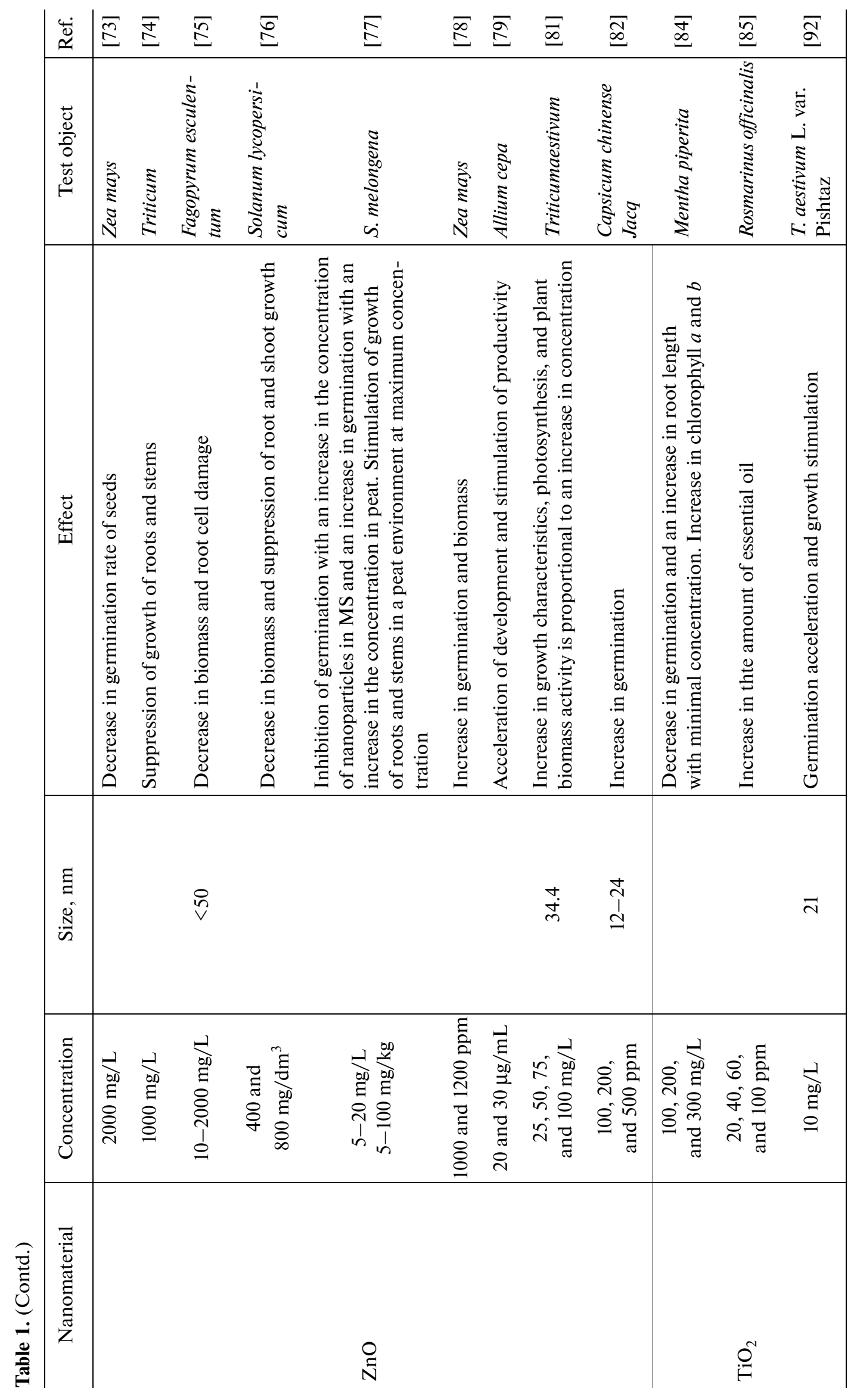


ana cells and accumulated in vacuoles and nuclei of root cells and vacuoles or structures similar to endosomes in hypocotyl, cotyledon, and leaf cells [90]. Although this internalization of $\mathrm{TiO}_{2}$ nanoparticles did not affect the cell viability and morphology, the authors assumed that the absorption and distribution of nanoparticles lead to cellular and molecular changes. Further studies showed that $\mathrm{TiO}_{2}$ ultrafine anatase nanoparticles led to reorganization and elimination of microtubules of Arabidopsis thaliana with subsequent high degradation of tubulin monomers depending on proteasome. $\mathrm{TiO}_{2}$ nanoparticles induce the isotropic growth of root cells like any other microtubule-destroying agents [91].

Moreover, some authors showed that titanium dioxide nanoparticles had positive effect on plant growth. Indeed, $\mathrm{TiO}_{2}$ at a concentration of $10 \mathrm{mg} / \mathrm{L}$ accelerated the germination of wheat seeds by $34 \%$ and contributed to a significant improvement in plant growth [92].

\section{CONCLUSIONS}

This review showed that $\mathrm{ZnO}$ and $\mathrm{TiO}_{2}$ nanoparticles can be used successfully as antimicrobial agents, and their biological effect depends on certain factors: photocatalytic activity, particle size, concentration, morphology, and surface modification (Table 1). The toxicity mechanisms, the primary one of which is the generation of reactive oxygen species leading to oxidative stress, are also due to these factors.

The data concerning the direct effect of $\mathrm{ZnO}$ and $\mathrm{TiO}_{2}$ nanoparticles on plants, however, are contradictory, which is probably due to the various particle shapes and sizes, their concentrations, and species characteristics of plants. Thus, the studies confirm that photocatalytically active $\mathrm{ZnO}$ and $\mathrm{TiO}_{2}$ nanoparticles may be used effectively as bactericidal and fungicidal drugs for sterilizing explants during clonal micropropagation of plants, but taking into account the possible phytotoxicity of these particles, which requires further study.

\section{FUNDING}

This work was conducted under a State Task of the Russian Ministry of Science and Education (project no. 14. 13544.2019 13.1).

\section{REFERENCES}

1. Y. H. Qin, J. A. T. Da Silva, J. H. Bi, et al., "Response of in vitro strawberry to antibiotics," Plant Growth Regul. 65, 183 (2011).

2. E. V. Tambarussi, M. Rogalski, F. T. S. Nogueira, et al., "Influence of antibiotics on indirect organogenesis of teak,” Ann. Forest Res. 58, 177 (2015).
3. J. Xia, K. Diao, Zh. Zheng, et al., "Porous $\mathrm{Au} / \mathrm{ZnO}$ nanoparticles synthesised through a metal organic framework (MOF) route for enhanced acetone gassensing," RSC Adv. 7, 38444 (2017).

4. Ch. Uboldi, P. Urban, D. Gilliland, et al., "Role of the crystalline form of titanium dioxide nanoparticles: rutile, and not anatase, induces toxic effects in Balb/3T3 mouse fibroblasts," Toxicol. Vitro 31, 137 (2016).

5. Y. Shang, M. K. Hasan, G. J. Ahammed, et al., "Applications of nanotechnology in plant growth and crop protection: a review," Molecules 24, 2558 (2019).

6. R. Brayner, R. Ferrari-Iliou, N. Brivois, et al., "Toxicological impact studies based on Escherichia coli bacteria in ultrafine $\mathrm{ZnO}$ nanoparticles colloidal medium," Nano Lett. 6, 866 (2006).

7. N. Jones, B. Ray, K. T. Ranjit, et al., "Antibacterial activity of $\mathrm{ZnO}$ nanoparticle suspensions on a broad spectrum of microorganisms," FEMS Microbiol. Lett. 279, 71 (2008).

8. R. Jalal, E. K. Goharshadi, M. Abareshi, et al., " $\mathrm{ZnO}$ nanofluids: green synthesis, characterization, and antibacterial activity," Mater. Chem. Phys. 121, 198 (2010).

9. J. T. Seil and T. J. Webster, "Antimicrobial applications of nanotechnology: methods and literature," Int. J. Nanomed. 7, 2767 (2012).

10. Z. Emami-Karvani and P. Chehrazi, "Antibacterial activity of $\mathrm{ZnO}$ nanoparticle on gram-positive and gramnegative bacteria," Afr. J. Microbiol. Res. 5, 1368 (2011).

11. N. Padmavathy and R. Vijayaraghavan, "Enhanced bioactivity of $\mathrm{ZnO}$ nanoparticles-an antimicrobial study," Sci. Technol. Adv. Mater. 9, 035004 (2008).

12. K. R. Raghupathi, R. T. Koodali, and A. C. Manna, "Size-dependent bacterial growth inhibition and mechanism of antibacterial activity of zinc oxide nanoparticles," Langmuir 27, 4020 (2011).

13. K. Kasemets, A. Ivask, H. C. Dubourguier, et al., "Toxicity of nanoparticles of $\mathrm{ZnO}, \mathrm{CuO}$, and $\mathrm{TiO}_{2}$ to yeast saccharomyces cerevisiae," Toxicol. Vitro 23, 1116 (2009).

14. L. Zhang, Y. Jiang, Y. Ding, et al., "Investigation into the antibacterial behaviour of suspensions of $\mathrm{ZnO}$ nanoparticles (ZnO nanofluids)," J. Nanopart. Res. 9, 479 (2007).

15. L. K. Adams, D. Y. Lyon, and P. J. Alvarez, "Comparative eco-toxicity of nanoscale $\mathrm{TiO}_{2}, \mathrm{SiO}_{2}$, and $\mathrm{ZnO}$ water suspensions," Water Res. 40, 3527 (2006).

16. J. Sawai, S. Shoji, H. Igarashi, et al., "Hydrogen peroxide as an antibacterial factor in zinc oxide powder slurry,” J. Biosci. Bioeng. 86, 521 (1998).

17. L. Zhang, Y. Ding, M. Povey, et al., "ZnO nanofluidsa potential antibacterial agent,” Prog. Nat. Sci.: Mater. Int. 18, 939 (2008).

18. J. Zhang, "Silver-coated zinc oxide nanoantibacterial synthesis and antibacterial activity characterization," in Proceedings of the 2011 International Conference on Electronics and Optoelectronics (ICEOE), Dalian, Liaoning, USA, July 29-31, 2011, Vol. 3, p. 94. https://doi.org/10.1109/ICEOE.2011.6013309

19. M. Nirmala, M. G. Nair, K. Rekha, et al., "Photocatalytic activity of $\mathrm{ZnO}$ nanopowders synthesized by DC thermal plasma,” Afr. J. Basic Appl. Sci. 2, 161 (2010). 
20. Proceedings of the Photoconductivity Conference, Atlantic City, Nov. 4-6, 1954, Ed. by R. G. Breckenridge, B. R. Russell, and E. E. Hahn (Wiley, New York, 1956).

21. O. Seven, B. Dindar, S. Aydemir, et al., "Solar photocatalytic disinfection of a group of bacteria and fungi aqueous suspensions with $\mathrm{TiO}_{2}, \mathrm{ZnO}$, and Sahara Desert dust,” J. Photochem. Photobiol. A 165, 103 (2004).

22. J. Bogdan, J. Pławińska-Czarnak, and J. Zarzyńska, "Nanoparticles of titanium and zinc oxides as novel agents in tumor treatment: a review," Nanoscale Res. Lett. 12, 225 (2017).

23. G. Zhou, Y. Li, W. Xiao, et al., "Synthesis, characterization, and antibacterial activities of a novel nanohydroxyapatite/zinc oxide complex," J. Biomed. Mater. Res. A 85, 929 (2008).

24. P. Joshi, S. Chakraborti, P. Chakrabarti, et al., "Role of surface adsorbed anionic species in antibacterial activity of ZnO quantum dots against escherichia coli," J. Nanosci. Nanotechnol. 9, 6427 (2009).

25. A. Stanković, S. Dimitrijević, and D. Uskoković, "Influence of size scale and morphology on antibacterial properties of $\mathrm{ZnO}$ powders hydrothermally synthesized using different surface stabilizing agents," Colloids Surf., B 102, 21 (2013).

26. N. Talebian, S. M. Amininezhad, and M. Doudi, "Controllable synthesis of $\mathrm{ZnO}$ nanoparticles and their morphology-dependent antibacterial and optical properties,” J. Photochem. Photobiol. A 120, 66 (2013).

27. J. Ma, J. Liu, Y. Bao, et al., "Synthesis of large-scale uniform mulberry-like $\mathrm{ZnO}$ particles with microwave hydrothermal method and its antibacterial property," Ceram. Int. 39, 2803 (2013).

28. P. J. P. Espitia, N. F. F. Soares, J. S. R. Coimbra, et al., "Zinc oxide nanoparticles: synthesis, antimicrobial activity, and food packaging applications," Food Bioprocess Technol. 5, 1447 (2012).

29. N. H. Harun R. B. S. M. N. Mydin, S. S. Sreekantan, et al., "Shape-dependent antibacterial activity against staphylococcus aureus of zinc oxide nanoparticles," Malays. J. Med. Health Sci. 14, 141 (2018).

30. H. Yang, C. Liu, D. Yang, et al., "Comparative study of cytotoxicity, oxidative stress and genotoxicity induced by four typical nanomaterials: the role of particle size, shape and composition," J. Appl. Toxicol. 29, 69 (2009).

31. G. Li, T. Hu, G. Pan, et al., "Morphology-function relationship of $\mathrm{ZnO}$ : polar planes, oxygen vacancies, and activity," J. Phys. Chem. C 112, 11859 (2008).

32. X. Peng, S. Palma, N. S. Fisher, et al., "Effect of morphology of $\mathrm{ZnO}$ nanostructures on their toxicity to Marine algae," Aquatic Toxicol. 102, 186 (2011).

33. O. Yamamoto, "Influence of particle size on the antibacterial activity of zinc oxide," Int. J. Inorg. Mater. 3, 643 (2001).

34. H. A. Jeng and J. Swanson, "Toxicity of metal oxide nanoparticles in mammalian cells," J. Environ. Sci. Health A 41, 2699 (2006).
35. O. Zakharova, E. Kolesnikov, E. Vishnyakova, et al., "Antibacterial activity of $\mathrm{ZnO}$ nanoparticles: dependence on particle size, dispersion media and storage time,” IOP Conf. Ser.: Earth Environ. Sci. 226, 012062 (2019).

36. R. Meraat, A. A. Ziabari, Kh. Issazadeh, et al., "Synthesis and characterization of the antibacterial activity of zinc oxide nanoparticles against Salmonella typhi," Acta Metall. Sin. (Engl. Lett.) 29, 601 (2016).

37. B. Kim, D. Kim, D. Cho, et al., "Bactericidal effect of $\mathrm{TiO}_{2}$ photocatalyst on selected food-borne pathogenic bacteria," Chemosphere 52, 277 (2003).

38. A. Azam, A. S. Ahmed, M. Oves, et al., "Antimicrobial activity of metal oxide nanoparticles against gram-positive and gramnegative bacteria: a comparative study," Int. J. Nanomed. 7, 6003 (2012).

39. M. Azimzadehirani, M. Elahifard, S. Haghighi, et al., "Highly efficient hydroxyapatite/ $\mathrm{TiO}_{2}$ composites covered by silver halides as $E$. coli disinfectant under visible light and dark media," Photochem. Photobiol. Sci. 12, 1787 (2013).

40. J. Lonnen, L. J. Kilvington, S. C. Kehoe, et al., "Solar and photocatalytic disinfection of protozoan, fungal, and bacterial microbes in drinking water," Water Res. 39, 877 (2005).

41. C. Sichel, J. Tello, M. de Cara, et al., "Effect of UV solar intensity and dose on the photocatalytic disinfection of bacteria and fungi," Catal. Today 129, 152 (2007).

42. A. K. Benabbou, Z. Derriche, C. Felix, et al., "Photocatalytic inactivation of escherichia coli-effect of concentration of $\mathrm{TiO}_{2}$ and microorganism, nature, and intensity of UV irradiation," Appl. Catal. B 76, 257 (2007).

43. A. Simon-Deckers, S. Loo, M. Mayne-L'Hermite, et al., "Size- composition- and shape-dependent toxicological impact of metal oxide nanoparticles and carbon nanotubes towards bacteria," Environ. Sci. Technol. 43, 8423 (2009).

44. B. Li and B. E. Logan, "The impact of ultraviolet light on bacterial adhesion to glass and metal oxide-coated surface," Colloids Surf. B 41, 153 (2005).

45. D. Friedmann, C. Mendive, and D. Bahnemann, " $\mathrm{TiO}_{2}$ for water treatment: parameters affecting the kinetics and mechanisms of photocatalysis," Appl. Catal. B 99, 98 (2010).

46. P. C. Maness, S. Smolinski, D. M. Blake, et al., "Bactericidal activity of photocatalytic $\mathrm{TiO}_{2}$ reaction: toward an understanding of its killing mechanism," Appl. Environ. Microbiol. 65, 4094 (1999).

47. T. Tong, C. T. Binh, J. J. Kelly, et al., "Cytotoxicity of commercial nano- $\mathrm{TiO}_{2}$ to Escherichia coli assessed by high-throughput screening: effects of environmental factors," Water Res. 47, 2352 (2013).

48. H. A. Foster, I. B. Ditta, S. Varghese, et al., "Photocatalytic disinfection using titanium dioxide: spectrum and mechanism of antimicrobial activity," Appl. Microbiol. Biotechnol. 90, 1847 (2011). 
49. Y. H. Tsunag, J. S. Sun, Y. C. Huang, et al., "Studies of photokilling of bacteria using titanium dioxide nanoparticles," Artif. Organs 32, 167 (2008).

50. L. Zhiyuan, Y. Shuili, P. Heedeung, et al., "Impact of titanium dioxide nanoparticles on the bacterial соммоль unities of biological activated carbon filter intended for drinking water treatment," Environ. Sci. Pollut. Res. 23, 15574 (2016).

51. C. L. de Dicastillo, C. Patiño, M. J. Galotto, et al., "Novel hollow titanium dioxide nanospheres with antimicrobial activity against resistant bacteria," Beilstein J. Nanotechnol. 19, 1716 (2019).

52. P. A. Arciniegas-Grijalba, M. C. Patiño-Portela, L. P. Mosquera-Sánchez, et al., "ZnO nanoparticles (ZnO-NPs) and their antifungal activity against coffee fungus erythricium salmonicolor," Appl. Nanosci. 7, 225 (2017).

53. A. Lipovsky, Y. Nitzan, A. Gedanken, et al., "Antifungal activity of $\mathrm{ZnO}$ nanoparticles-the role of ROS mediated cell injury," Nanotecnology 22, 105101 (2011).

54. L. He, Y. Liu, A. L. Mustapha, et al., "Antifungal activity of zinc oxide nanoparticles against Botrytis cinerea and Penicillium expansum," Microbiol. Res. 166, 207 (2011)

55. S. C. de la Rosa-García, P. Martínez-Torres, S. Gómez-Cornelio, et al., "Antifungal activity of $\mathrm{ZnO}$ and $\mathrm{MgO}$ nanomaterials and their mixtures against colletotrichum gloeosporioides strains from tropical fruit," J. Nanomater., 3498527 (2018).

56. D. Sardell, R. Gatt, and V. P. Valdramidisa, "Assessing the efficacy of zinc oxide nanoparticles against penicillium expansum by automated turbidimetric analysis," Mycology 9, 43 (2018).

57. T. Matsunaga, R. Tomoda, T. Nakajima, et al., "Photoelectrochemical sterilization of microbial cells by semiconductor powders," FEMS Microbiol. Lett. 29, 211 (1985).

58. S. Thabet, F. Simonet, M. Lemaire, et al., "Impact of photocatalysis on fungal cells: depiction of cellular and molecular effects on Saccharomyces cerevisiae," Appl. Environ. Microbiol. 80, 7527 (2014).

59. N. Akiba, I. Hayakawa, E. S. Keh, et al., "Antifungal effects of a tissue conditioner coating agent with $\mathrm{TiO}_{2}$ photocatalyst,” J. Med. Dent. Sci. 52, 223 (2005).

60. D. Mitoraj, A. Jańczyk, M. Strus, et al., "Visible light inactivation of bacteria and fungi by modified titanium dioxide," Photochem. Photobiol. Sci. 6, 642 (2007).

61. I. Perelshtein, G. Applerot, N. Perkas, et al., "A onestep process for the antimicrobial finishing of textiles with crystalline $\mathrm{TiO}_{2}$ nanoparticles," Chem.-Eur. J. 18, 4575 (2012).

62. G. Xiao, X. Zhang, Y. Zhao, et al., "The behavior of active bactericidal and antifungal coating under visible light irradiation,” Appl. Surf. Sci. 292, 756 (2014).

63. C. Sichel, M. de Cara, J. Tello, et al., "Solar photocatalytic disinfection of agricultural pathogenic fungi: fusarium species,” Appl. Surf. Sci. 74, 152 (2007).
64. K. P. Yu, Y. T. Huang, and S. C. Yang, "The antifungal efficacy of nano-metals supported $\mathrm{TiO}_{2}$ and ozone on the resistant aspergillus niger spore," J. Hazard. Mater. 261, 155 (2013).

65. S. Y. Ye, M. L. Fan, X. L. Song, et al., "Enhanced photocatalytic disinfection of $\mathrm{p}$. expansum in cold storage using a $\mathrm{TiO}_{2} / \mathrm{ACF}$ film," Int. J. Food Microbiol. 136, 332 (2010).

66. E. Barreto-Bergter and R. T. Figueiredo, "Fungal glycans and the innate immol une recognition," Front. Cell. Infection Microbiol. 4, 145 (2014).

67. G. de Filpo, A. M. Palermo, F. Rachiele, et al., "Preventing fungal growth in wood by titanium dioxide nanoparticles," Int. Biodeterior. Biodegrad. 85, 217 (2013).

68. R. Sagardoy, F. Morales, A. F. Lopez-Millan, et al., "Effects of zinc toxicity on sugar beet (Beta vulgaris L.) plants grown in hydroponics," Plant Biol. 11, 339 (2009).

69. S. K. Gupta, A. K. Rai, S. S. Kanwar, et al., "Comparative analysis of zinc finger proteins involved in plant disease resistance," PLoS One 7 (8), e42578 (2012).

70. S. Mishra and R. S. Dubey, "Heavy metal toxicity induced alterations in photosynthetic metabolism in plants," in Handbook of Photosynthesis, Ed. by M. Pessarakli, 2nd ed. (CRC, Taylor and Francis, New York, 2005), p. 845.

71. S. R. Mousavi, M. Galavi, and M. Rezaei, "Zinc (Zn) importance for crop production-a review," Int. J. Agron. Plant Prod. 4, 64 (2013).

72. A. Kleckerova, P. Sobrova, and O. Krystofova, "Cadmium(II) and zinc(II) ions effects on maize plants revealed by spectroscopy and electrochemistry," Int. J. Electrochem. Sci. 6, 6011 (2011).

73. D. Lin and B. Xing, "Phytotoxicity of nanoparticles: inhibition of seed germination and root growth," Environ. Pollut. 150, 243 (2007).

74. S. Kumar, A. K. Patra, S. C. Datta, et al., "Phytotoxicity of nanoparticles to seed germination of plants," Int. J. Adv. Res. 3, 854 (2015).

75. S. Lee, H. Chung, S. Kim, et al., "The genotoxic effect of $\mathrm{ZnO}$ and $\mathrm{CuO}$ nanoparticles on early growth of buckwheat, fagopyrum esculentum," Water Air Soil Pollut. 224, 1668 (2013).

76. X. P. Wang, Q. Q. Li, Z. M. Pei, et al., "Effects of zinc oxide nanoparticles on the growth, photosynthetic traits, and antioxidative enzymes in tomato plants," Biol. Plant. 62, 801 (2018).

77. T. Thunugunta, R. Channa, S. Kodthalu, et al., "Impact of zinc oxide nanoparticles on eggplant (S. melongena): studies on growth and the accumulation of nanoparticles," IET Nanobiotechnol. 12, 706 (2018).

78. D. S. Meena, H. M. Jayadeva, Ch. Gautam, et al., "Effects of nano zinc oxide $(\mathrm{ZnO})$ particles on germination of Maize (Zea mays L.) seeds," Int. J. Plant Soil Sci. 16, 1 (2017).

79. S. V. Raskar and S. L. Laware, "Influence of zinc oxide nanoparticles on growth, floweringand seed productiv- 
ity in onion,” Int. J. Curr. Microbiol. Appl. Sci. 3, 874 (2014).

80. Z. Hafizi and N. Nasr, "The effect of zinc oxide nanoparticles on safflower plant growth and physiology,” Eng., Technol. Appl. Sci. Res. 8, 508 (2018).

81. T. Munir, M. Rizwan, M. Kashif, et al., "Effect of zinc oxide nanoparticles on the growth and $\mathrm{Zn}$ uptake in wheat (Triticumaestivum L.) by seed priming method," Digest J. Nanomater. Biostruct. 13, 315 (2018).

82. J. I. García-López, F. Zavala-García, E. OlivaresSáenz, et al., "Zinc oxide nanoparticles boosts phenolic compounds and antioxidant activity of Capsicum annuum L. during germination," Agronomy 8 (10), 215 (2018).

83. J. I. García-López, G. Niño-Medina, E. OlivaresSáenz, et al., "Foliar application of zinc oxide nanoparticles and zinc sulfate boosts the content of bioactive compounds in habanero peppers," Plants 8 (8), 254 (2019).

84. N. Samadi, S. Yahyaabadi, and Z. Rezayatmand, "Effect of $\mathrm{TiO}_{2}$ and $\mathrm{TiO}_{2}$ nanoparticle on germination, root, and shoot length and photosynthetic pigments of mentha piperita,” Int. J. Plant Soil Sci. 3, 408 (2014).

85. A. Golami, H. Abbaspour, H. Hashemi-Moghaddam, and M. Gerami, "Photocatalytic effect of $\mathrm{TiO}_{2}$ nanoparticles on essential oil of Rosmarinus officinalis,” J. Biochem. Technol. 9 (4), 50 (2018).

86. R. Raliya, R. Nair, S. Chavalmane, et al., "Mechanistic evaluation of translocation and physiological impact of titanium dioxide and zinc oxide nanoparticles on the tomato (Solanum lycopersicum L.) plant," Metallomics 7, 1584 (2015).

87. U. Song, H. Jun, B. Waldman, et al., "Functional analyses of nanoparticle toxicity: a comparative study of the effects of $\mathrm{TiO}_{2}$ and $\mathrm{Ag}$ on tomatoes (Lycopersicon esculentum)," Ecotoxicol. Environ. Safety 93, 60 (2013).

88. M. Castiglione, L. Giorgetti, C. Geri, et al., "The effects of nano- $\mathrm{TiO}_{2}$ on seed germination, development, and mitosis of root tip cells of Vicia narbonensis L. and Zea mays L.," J. Nanopart. Res. 13, 2443 (2011).

89. C. Larue, H. Khodja, N. Herlin-Boime, et al., "Investigation of titanium dioxide nanoparticles toxicity and uptake by plants," J. Phys.: Conf. Ser. 304, 012057 (2011).

90. J. Kurepa, T. Paunesku, S. Vogt, et al., "Uptake and distribution of ultrasmall anatase $\mathrm{TiO}_{2}$ alizarin Red $\mathrm{S}$ nanoconjugates in Arabidopsis thaliana," Nano Lett. 10, 2296 (2010).

91. S. Wang, J. Kurepa, and J. A. Smalle, "Ultra-small $\mathrm{TiO}_{2}$ nanoparticles disrupt microtubular networks in arabidopsis thaliana," Plant, Cell Environ. 34, 811 (2011).

92. H. Feizi, P. Moghaddam, N. Shahtahmassebi, et al., "Impact of bulk and nanosized titanium dioxide $\left(\mathrm{TiO}_{2}\right)$ on wheat seed germination and seedling growth," Biolog. Trace Elem. Res. 146, 101 (2012).

Translated by A. Tulyabaev 